\title{
Analysis of The Color Purple from Freud's Psychoanalysis
}

\author{
Caixia $\mathrm{Si}$ \\ Huanghe Science and Technology College \\ Zhenghou, China
}

\begin{abstract}
An American writer Alice Walker's The Color Purple is an outstanding epistolary novel. It tells a story of Celie, a young black girl growing up in the South of the United States. As a victim of the society, she learns to write letters to God in which she tells God what happens in her personal life. There are many reasons contributing to Celie's growth from an oppressed black woman without soul to an independent new woman. This paper tries to interpret Celie's growth from the perspective of Freud's psychoanalysis, especially from his theory of personality.
\end{abstract}

\section{Growth}

Keywords-Freud; Psychoanalysis; Celie; Personality;

\section{INTRODUCTION}

Alice Walker's The Color Purple, as the most influential work of the black literature, has won her both the American Book Award and Pulitzer Prize. As an outstanding epistolary novel, The Color Purple is composed of 90 letters, 61 of which are letters from Celie to God, 14 from Celie to Nettie and 15 from Nettie to Celie. It tells a story of Celie, a young black girl growing up in the South of the United States during the reconstruction period. As a victim of her society, she learns to write letters to God in which she tells the latter what happens in her personal life.

With the procession of the story, Celie gradually grows up and undergoes the process of transformation and selfrealization. The story centers on Celie's life, with Nettie's African adventure as complementary. This paper tries to interpret Celie's growth from the perspective of Freud's psychoanalysis, especially from his theory of personality.

\section{INTRODUCTION TO FREUD’S PSYCHOANALYSIS}

According to Freud, human mind can be divided into two main parts: the conscious and the unconscious mind. The conscious mind includes everything that we are aware of. The unconscious mind is a reservoir of feelings, thoughts, urges, and memories that are outside of our conscious awareness. Most of the contents of the unconscious are unacceptable or unpleasant, such as feelings of pain, anxiety, or conflict. According to Freud, the unconscious continues to influence our behavior and experience, even though we are unaware of these underlying influences.

According to Freud, the key to a healthy personality is a balance between the id, the ego, and the superego.

\section{ANALYSIS OF CELIE'S GROWTH FROM FREUD'S PSYCHOANALYSIS}

In The Color Purple, Celie, as an oppressed black woman, leads a miserable life at the beginning: She was raped by her stepfather and had to keep silent, for his stepfather warned her "You better not never tell nobody but God. It'd kill your mammy" (Alice Walker 3). After her stepfather was tired of her, he turned his attention to her sister, Nettie. In order to protect her sister who seems to be the only one she really cares about, she sacrifices herself and gets married to Mr. whose first choice, however, is Nettie. He marries her just because he is in bad need of a woman to look after his four children and the hard work in the field. In a certain way, we can say that her most obvious personality is that she has no "personality". In the patriarchal black community, she is oppressed and invisible. She has no sense of self-identity, always silent.

In this work, Celie's life is full of miseries and her basic rights as a human cannot be satisfied. If she let those desires be repressed into the unconscious, she cannot be a normal and healthy person. She does not choose the usual sexual way, just like her stepfather and $\mathrm{Mr}$._ to relieve the tension, for she does not get any joy from it.

Though Christianity helps her to survive, it also makes her a "silent" person without any passion towards life.

But later, with Shug Avery and Sophia, her superego gradually changes and it is this change that makes her life totally different and become brilliant and wonderful.

Shug, as a Blues singer, is different from Celie. She is independent and courageous, always fighting for her own independence and individuality. She defies the authority of man and does everything she wants to. She does not believe the superior God, thinking that "God is inside you and inside everybody else. You come into the world with God. But only them that search for it inside find it" (Alice Walker 166). "God ain't a he or a she, but a It" (Alice Walker 167). The faith she believes in is that black women can do whatever they want to do and could not be suppressed by men. They must fight for their own individuality.

Sophia's personality is much the same way like Shug, though at last she surrenders and becomes the maid of the mayor. All her life she had to fight, fighting for her own identity and her own voice. But, in the beginning, when 
Harpo asked Celie's advice how to get the upper hand in their relationship, she advised him to beat her. They two actually represent the real superego that is really helpful for the regain of black women's identity. It is due to the change of the superego that Celie can go out of the family and run her own business.

\section{CONCLUSION}

In this sense, Alice Walker tries to tell us that it is important for the black women to forsake the traditional beliefs which contribute only to making them silent and devoiced. The male-dominated beliefs are not suitable for them either, for those beliefs promote the inequality between the two genders. The way for them to get recognized is to find their own superego and get united to fight for their own rights.

\section{REFERENCES}

[1] Brill, A. A. Freud's Principles of Psychoanalysis: Basic Principles of Psychoanalysis. Montana, USA : Kessinger Publishing, LLC, 2007.

[2] Shui Caiqin. "Walker's Thematic Concern Revealed by the Black Males from the Novel: The Color Purple." Journal of Huaihua University 5 (2007): 25.

[3] Walker, Alice. The Color Purple. New York \& London: Harcourt Brace Jovanovich Publisher, 1982. 